\title{
Analisis Faktor Risiko Kejadian Preeklampsia Di Manado
}

\author{
Elisabeth M.F. Lalita \\ Poltekkes Kemenkes Manado, \\ lisalalita08@gmail.com
}

Naskah Diterima : 08 Desember 2018

Disetujui : 29 Desember 2018

Publikasi : Januari 2019

\begin{abstract}
ABSTRAK
Latar Belakang : Preeklampsia merupakan salah satu masalah medis yang menyebabkan morbiditas pada ibu dan janin serta penyebab kematian pada ibu. Preeklampsia ialah penyakit yang ditandai dengan tekanan darah tinggi (hipertensi), pembengkakan jaringan (edema), dan ditemukannya protein dalam urin (proteinuria) yang timbul karena kehamilan. Faktor-faktor risiko preeklampsia antara lain faktor umur, paritas, status gizi, riwayat hipertensi, riwayat keluarga, riwayat preeklampsia/ eklampsia dan pemeriksaan antenatal.

Tujuan : untuk mengidentifikasi faktor risiko kejadian preeklampsia.

Metode : Jenis penelitian ialah observasional dengan rancangan case-control study. Tempat penelitian di laksanakan di RSUP Prof. Dr. R.D. Kandou Manado, dengan jumlah sampel 44 kasus dan 44 kontrol. Data yang diperoleh kemudian dianalisis menggunakan uji chi-square, selanjutnya dilakukan juga analisis multivariat menggunakan uji regresi logistik ganda.

Hasil : menunjukkan bahwa 1) terdapat hubungan yang signifikan antara umur, paritas, riwayat hipertensi, riwayat keluarga, riwayat preeklampsia dengan kejadian preeklampsia; 2) tidak terdapat hubungan antara obesitas dan pemeriksaan antenatal dengan kejadian preeklampsia; Disarankan untuk instansi unit pelayanan kesehatan yang ada di RSUP Prof. Dr. R.D. Kandou Manado dalam pengelolaan Pelayanan Kegawatdaruratan Obstetri dan Neonatal Emergensi Komprehensif (PONEK) agar dapat dilakukan dengan cepat sehingga kasus preeklampsia pada ibu hamil dapat terdeteksi sedini mungkin dan dapat tertangani oleh tenaga kesehatan dengan tepat.
\end{abstract}

\section{Kata Kunci : Preeklampsia, Faktor risiko}

\section{PENDAHULUAN}

Preeklampsia merupakan salah satu masalah medis yang menyebabkan morbiditas pada ibu serta morbiditas pada janin. Selain itu, preeklampsia masih merupakan sumber utama penyebab kematian pada ibu ${ }^{(1)}$. Preeklampsia ialah penyakit yang ditandai dengan tekanan darah tinggi (hipertensi), pembengkakan jaringan (edema), dan ditemukannya protein dalam urin (proteinuria) yang timbul karena kehamilan. Penyakit ini umumnya terjadi dalam triwulan ke-3 kehamilan, tetapi dapat juga terjadi pada trimester kedua kehamilan (1)
Angka Kematian Ibu (AKI) menurut Survei Demografi Kesehatan Indonesia (SDKI) tahun 2007 yaitu 228 per 100.000 kelahiran hidup. Angka ini mengalami kenaikan secara signifikan pada tahun 2012 menjadi 359 per 100.000 kelahiran hidup). Angka Kematian Ibu (AKI) merupakan salah satu indikator untuk melihat derajat kesehatan perempuan. Kematian ibu di Indonesia tetap didominasi oleh tiga penyebab utama kematian yaitu perdarahan, preeklampsia atau hipertensi dalam kehamilan dan infeksi. Proporsi ketiga penyebab kematian ini telah berubah, dimana perdarahan dan infeksi 
semakin menurun sedangkan preeklampsia atau hiperetensi dalam kehamilan (HDK) proporsinya semakin meningkat, dimana hampir $30 \%$ kematian ibu di Indonesia pada tahun 2011 disebabkan oleh HDK ${ }^{\text {(2) }}$

Faktor-faktor yang dapat meningkatkan risiko preeklampsia yaitu nulliparitas, usia ibu yang lebih tua, kelahiran kembar, diabetes, hipertensi kronis, obesitas, riwayat preeklampsia, sebelumnya, riwayat keluarga preeclampsia (3). Menurut penelitian yang meneliti di RSIA Siti Fatimah Makasar, faktor umur ibu hamil < 20 tahun atau > 35 tahun berisiko 2,1 kali terjadi preeklampsia. Demikian juga hasil penelitian yang dilakukan di RS Dr.H. Soewondo Kendal bahwa faktor paritas mempunyai risiko untuk terjadi preeklampsia sebesar 4,75 kali dibandingkan wanita hamil yang kedua atau ketiga (multigravida). ${ }^{(6)}$ Faktor lain juga menunjukkan bahwa faktor obesitas mempunyai peluang 2,8 kali terhadap kejadian preeklampsia, ${ }^{(7)}$ demikian juga dengan hasil penelitian yang dilakukan di RSU Tanjung Pura Kabupaten Langkat untuk pengukuran lingkar lengan atas (LILA) berpengaruh terhadap kejadian hipertensi ibu hamil dengan nilai $p$ 0,030. (8) Faktor lainnya yang berpengaruh yakni pemeriksaan selama masa kehamilan atau antenatal care (ANC). Setiap kehamilan dapat berkembang menjadi masalah atau komplikasi setiap saat, itu sebabnya mengapa ibu hamil memerlukan pemantauan selama kehamilannya $(\mathbf{9})(\mathbf{1 0})$

Data Provinsi Sulawesi Utara Tahun 2016 menunjukkan jumlah kematian ibu sebanyak 77 kasus yang terdiri atas penyebab perdarahan sebanyak 28 kasus, preeklampsia/eklampsia sebanyak 18 kasus, infeksi 1 kasus, partus lama 1 kasus, dan penyebab lain sebanyak 29 kasus. Berdasarkan hasil survey pendahuluan di RSUP Prof. Dr. R.D. Kandou, data tahun 2016 menunjukkan bahwa dari 3.100 ibu hamil yang datang memeriksakan kehamilannya di RS tersebut, terdapat 686 ibu hamil $(22,2 \%)$ dengan preeklampsia. Tujuan penelitian ini ialah mengidentifikasi faktor risiko kejadian preeclampsia.

\section{METODE}

Jenis penelitian ini ialah penelitian observasional analitik dengan case control study design. Tempat penelitian dilakukan di RSUP Prof. Dr. R.D. Kandou. Waktu penelitian dilaksanakan pada bulan Juni sampai Juli 2017. Populasi ialah seluruh ibu hamil yang melakukan kunjungan pemeriksaan di Poliklinik Obstetri dan Instalasi Rawat Darurat Obs-Gyn pada bulan Juni sampai Juli 2017. Pengambilan sampel dlakukan secara accidental sampling dan kontrol diambil 1:1, sehingga jumlah sampel pada kelompok kasus sebanyak 44 responden dan kontrol sebanyak 44 responden. Jumlah sampel seluruhnya 88 responden. Analisa data menggunakan uji Chi Square mengetahui besar risiko (Odds Ratio) paparan terhadap kasus pada tingkat kepercayaan $95 \%$ dan Regresi Logistik.

\section{HASIL}

Analisis dilakukan untuk mengetahui besar risiko (Odds Ratio) pada faktor kejadian Preeklampsia. 
Tabel 1. Odds Ratio Kejadian Preeklampsia pada Kasus dan Kontrol di RSUP Prof. Dr. R.D. Kandou Tahun 2017

\begin{tabular}{|c|c|c|c|c|c|c|c|c|}
\hline \multirow{2}{*}{ Variabel } & \multirow{2}{*}{ Kategori } & \multicolumn{4}{|c|}{ Kejadian Preeklampsia } & \multirow{2}{*}{ Total } & \multirow{2}{*}{ Nilai $\mathrm{p}$} & \multirow{2}{*}{$\begin{array}{c}\text { OR } \\
(95 \% \mathrm{CI})\end{array}$} \\
\hline & & Kasus & $\%$ & Kontrol & $\%$ & & & \\
\hline \multirow[t]{2}{*}{ Umur } & $<21$ dan $>35$ tahun & 11 & 12,5 & 20 & 22,7 & 31 & \multirow[t]{2}{*}{0,045} & 0.4 \\
\hline & 21-35 tahun & 33 & 37,5 & 24 & 27,3 & 57 & & $(0.16-0.98)$ \\
\hline \multirow[t]{2}{*}{ Paritas } & Primi dan Grande & 34 & 38,6 & 24 & 27,3 & 58 & \multirow[t]{2}{*}{0,025} & 2.8 \\
\hline & Multigravida & 10 & 11,4 & 20 & 22,7 & 30 & & $(1.12-7.12)$ \\
\hline \multirow[t]{2}{*}{ Obesitas } & $\mathrm{Ya}$ & 35 & 39,8 & 28 & 31,8 & 63 & \multirow[t]{2}{*}{0,098} & 2.2 \\
\hline & Tidak & 9 & 12,5 & 16 & 18,2 & 25 & & $(0.85-5.78)$ \\
\hline \multirow{2}{*}{$\begin{array}{l}\text { Riwayat } \\
\text { Hipertensi }\end{array}$} & Ada riwayat & 32 & 36,4 & 17 & 19,3 & 49 & \multirow[t]{2}{*}{0,001} & 4.2 \\
\hline & Tidak ada riwayat & 12 & 13,6 & 27 & 30,7 & 39 & & $(1.72-10.40)$ \\
\hline \multirow{2}{*}{$\begin{array}{l}\text { Riwayat } \\
\text { Keluarga }\end{array}$} & Ada riwayat & 27 & 61,4 & 13 & 29,5 & 40 & \multirow[t]{2}{*}{0,003} & 3,8 \\
\hline & Tidak ada riwayat & 17 & 38,6 & 31 & 70,5 & 48 & & $(1.55-9.20)$ \\
\hline \multirow{2}{*}{$\begin{array}{l}\text { Riwayat } \\
\text { Preeklamsia }\end{array}$} & Ada riwayat & 24 & 54,5 & 14 & 31,8 & 38 & \multirow[t]{2}{*}{0,031} & 2.6 \\
\hline & Tidak ada riwayat & 20 & 45,5 & 30 & 68,2 & 50 & & $(1.07-6.13)$ \\
\hline \multirow{2}{*}{$\begin{array}{l}\text { Pemeriksaan } \\
\text { Antenatal }\end{array}$} & Tidak sesuai & 23 & 26,1 & 15 & 17 & 38 & \multirow[t]{2}{*}{0,085} & 2.1 \\
\hline & Sesuai & 21 & 23,9 & 29 & 33 & 50 & & $(0.89-5.00)$ \\
\hline
\end{tabular}

Analisis terhadap model akhir regresi yaitu variabel bebas yang memiliki hubungan signifikan $(\mathrm{p}<0,05)$ dengan kejadian preeklampsi yaitu paritas dan riwayat hipertensi. Kekuatan hubungan antara variabel bebas dengan kejadian preeklampsi yaitu riwayat hipertensi (OR adjusted $=5,24 ; 95 \%$ CI : 1.985-13.846) dan variabel paritas (OR adjusted $=3,77$; 95\% CI : 1.356-10.509). Kelompok dengan riwayat hipertensi memiliki risiko terajadi preeklampsi sebesar 5,3 kali lebih tinggi dibandingkan dengan kelompok yang tidak ada riwayat hipertensi setelah dikontrol dengan paritas. Kelompok dengan paritas primigravida dan atau grandegravida memiliki peluang terjadi preeklampsi sebesar 3,8 kali lebih tinggi dibandingkan dengan kelompok dengan paritas multigravida.

\section{PEMBAHASAN}

\section{a. Umur Dengan Kejadian}

\section{Preeklampsia}

Umur ibu pada saat kehamilan merupakan salah satu faktor yang menentukan tingkat risiko kehamilan dan persalinan. Wanita yang berusia kurang dari 20 tahun dan lebih dari 35 tahun mempunyai risiko tinggi terhadap kejadian preeklampsia. Berdasarkan hasil uji statistik dengan uji chi kuadrat diperoleh nilai p sebesar $0,045(<0,05)$ dan nilai OR 0,4 maka secara statistik dikatakan bermakna antara umur ibu dengan kejadian preeklampsi, sehingga hal ini dapat disimpulkan sebaliknya umur $<21$ tahun atau >35 tahun akan lebih berisiko terjadi preeklampsia sesuai dengan teori dan penelitian yang dilakukan oleh ${ }^{(11)}$ 
menyatakan bahwa usia yang aman untuk hamil pada usia 25 sampai 29 tahun dengan nilai OR 2,3 (95\% CI 1,28-4,09), penelitian lain menunjukkan bahwa ibu yang berusia $<21$ tahun dan > 35 tahun merupakan faktor risiko terhadap kejadian preeklampsi dengan OR 3,73. (12) Hal yang sama juga menunjukkan bahwa hubungan yang bermakna antara umur ibu melahirkan dengan kejadian preeklampsi. Risiko kejadian preeklampsi ibu melahirkan dengan umur $<21$ tahun dan $>35$ tahun adalah 3,67 kali lebih besar dari umur ibu 21 sampai 35 tahun. ${ }^{\text {(13) }}$

\section{b. Paritas Dengan Kejadian Preeklampsia.}

Paritas adalah jumlah anak yang telah dilahirkan oleh seorang ibu baik lahir hidup maupun mati. Faktor paritas memiliki pengaruh terhadap persalinan dikarenakan ibu hamil memiliki risiko lebih tinggi untuk mengalami gangguan selama masa kehamilannya terlebih pada ibu yang pertama kali mengalami masa kehamilan. Berdasarkan hasil uji statistik bivariat dengan uji chi kuadrat diperoleh nilai OR 2,8 (CI) $95 \%$ artinya ibu hamil dengan jumlah paritas satu anak atau lebih dari empat anak mempunyai peluang 2,8 kali untuk terjadi preeklampsia, penelitian yang sama menunjukkan bahwa paritas merupakan faktor risko terhadap kejadian preeklampsia dengan nilai OR 4,7 dengan nilai $\mathrm{p} 0,031$.

Hal ini tidak berbeda dengan teori yang mengatakan bahwa salah satu predisposisi terjadinya preeklampsia adalah faktor paritas (primigravida atau grandemultgravida), juga dari teori lain maupun hasil penelitian yang terdahulu telah banyak dibuktikan, dari kejadian $80 \%$ semua kasus hipertensi pada kehamilan, 3 $8 \%$ pasien terutama pada primigravida, pada kehamilan trimester kedua

Catatan statistik menunjukkan dari seluruh insiden dunia, dari 5\%-8\% preeklampsia dari semua kehamilan, terdapat $12 \%$ lebih dikarenakan oleh primigravida ${ }^{(\mathbf{1 5})}$. Faktor yang mempengaruhi preeklampsia frekuensi primigravida lebih tinggi bila dibandingkan dengan multigravida, terutama primigravida muda. ${ }^{(16)}$

\section{c. Obesitas \\ Dengan \\ Kejadian \\ Preeklampsia.}

Berdasarkan hasil uji statistik dengan uji chi kuadrat diperoleh nilai $\mathrm{p}$ sebesar $0,098(>0,05)$ maka secara statistik menunjukkan bahwa tidak ada hubungan obesitas dengan kejadian preeklampsi, hasil penelitian ini sama menunjukkan bahwa tidak ada perbedaan yang bermakna antara ibu yang obesitas dengan terjadinya preeklampsia berat $(\mathrm{p}=0,59)$. (6) Menurut asumsi peneliti hasil ini dapat disebabkan karena kasus preeklampsia terjadi pada semua ibu hamil baik ibu hamil yang mengalami obes maupun ibu hamil yang tidak obes.

Pertambahan berat badan selama kehamilan sebagian besar diakibatkan uterus dan isinya, payudara, dan peningkatan volume darah serta cairan ekstravasikuler. Peningkatan berat badan ibu selama kehamilan menandakan adaptasi ibu terhadap pertumbuhan janin, pertambahan berat badan rata-rata sebanyak 12,5 kg. ${ }^{(18)}$

\section{d. Riwayat Hipertensi dengan Kejadian Preeklampsi}

Pada penelitian ini, responden yang mempunyai riwayat hipertensi lebih banyak 
bila dibandingkan dengan jumlah responden yang tidak mempunyai riwayat hipertensi, dari semua kasus preeklampsi, responden yang mempunyai riwayat hipertensi sebanyak 72,7\%, sedangkan pada kontrol yang mempunyai riwayat hipertensi sebanyak 38,6\%. Hasil bivariat dengan menggunakan uji Chi Kuadrat didapatkan nilai OR 4,2 artinya seorang ibu hamil dengan riwayat hipertensi mempunyai peluang 4,2 kali terjadi preeklampsia, kemudian dilakukan analisis multivariat menunjukkan adanya hubungan yang sangat signifikan antara kejadian preeklampsi dengan responden yang mempunyai riwayat hipertensi dan hubungan ini mempunyai keeratan yang cukup tinggi dengan risiko 5,3 kali. Hasil penelitian ini sesuai dengan penelitian yang menunjukkan bahwa riwayat hipertensi merupakan faktor risiko terhadap kejadian preeklampsia dengan nilai OR 2,98 dengan nilai $\mathrm{p} 0,004$. ${ }^{(6)}$ Menurut teori kehamilan dapat menyebabkan hipertensi pada wanita yang sebelumnya dalam keadaan normal atau memperburuk hipertensi pada wanita yang sebelumnya telah menderita hipertensi atau mempunyai riwayat hipertensi. Hipertensi sebagai penyulit dalam kehamilan sering ditemukan dan merupakan salah satu dari tiga besar, selain pendarahan dan infeksi, yang terus menjadi penyebab utama kematian ibu di Amerika Serikat. (20)

\section{e. Riwayat Keluarga Dengan Kejadian Preeklampsia.}

Pada analisis bivariat faktor riwayat keluarga terdapat hubungan yang sangat signifikan dengan terjadinya preeklampsia dan mempunyai risiko 3,8 kali untuk terjadi preeklampsi pada mereka yang mempunyai keturunan dengan hipertensi dibandingkan dengan mereka yang tidak mempunyai keturunan dengan hipertensi. Hasil penelitian ini sejalan dengan hasil penelitian sebelumnya yang menunjukkan risiko 7,11 kali untuk terjadi preeklampsi. (17)

Demikian juga adanya fakror genetik pada keluarga akan menyebabkan keluarga tersebut mempunyai resiko menderita hipertensi. Individu yang memiliki orang tua dengan hipertensi mempunyai dua kali lebih besar untuk menderita hipertensi dari ada individu yang tidak mempunyai keluarga dengan riwayat hipertensi.

Hipertensi merupakan penyakit degeneratif dan tidak terlepas dari faktor keturunan. Kalau ada keluarga yang memiliki penyakit hipertensi, maka sangat besar ibu hamil tersebut mengalaminya. Sebuah penelitian menunjukkan bahwa ada bukti gen yang diturunkan untuk masalah tekanan darah tinggi. Hasil penelitian menyatakan bahwa peranan riwayat keluarga terhadap timbulnya hipertensi terbukti dengan ditemukan kejadian bahwa hipertensi lebih banyak pada kembar monozigot (satu sel telur) dari pada heterozigot (berbeda sel telur). Tekanan darah terkait erat dengan riwayat keluarga seseorang. Seseorang yang kedua orang tuanya menderita hipertensi akan memiliki kemungkinan 50-75\% untuk menjadi hipertensi. Pada riwayat keluarga merupakan faktor resiko yang tidak dapat dikontrol sehingga kejadian hipertensi terjadi pada ibu hamil

\section{f. Riwayat Preeklampsi Dengan Kejadian Preeklampsia.}

Hasil analisis bivariat nilai $\mathrm{p} 0,03$ menunjukkan adanya hubungan yang sangat signifikan antara kejadian 
preeklampsi dengan responden yang mempunyai riwayat preeklampsi dan hubungan ini mempunyai keeratan yang cukup dengan risiko 2,571 kali. Hasil ini sama juga dengan penelitian yang dilakukan oleh Agung Supriandono dan Sulchan Sofoewan menyebutkan terdapat $50,9 \%$ kasus preeklampsia mempunyai riwayat preeklampsia, dan pada kelompok kontrol terdapat $7,3 \%$ mempunyai riwayat preekalmpsia, dengan risiko sampai $13 \mathrm{kali}$ untuk terjadi preeklampsia bagi ibu hamil yang mempunyai riwayat keturunan dalam keluarga.

Banyak teori mengatakan bahwa penyebab terjadinya preeklampsia belum diketahui secara pasti, para ilmuwan mensinyalir bahwa terjadinya preeklampsi disebabkan oleh faktor hormonal, tetapi teori juga mengatakan bahwa salah satu faktor predisposing terjadinya preekalampsi adalah mereka ibu hamil yang mempunyai riwayat preeklampsia atau eklampsia pada kehamilan sebelumnya.

Beberapa bukti menunjukkan peran faktor genetik pada kejadian preeklampsia antara lain (1) terdapatnya kecenderungan meningkatnya frekuensi preeklampsia pada anak-anak dari ibu yang menderita preeklampsia / eklampsia,

kecenderungan meningkatnya frekuensi preeklampsia/ eklampsia pada anak dan cucu ibu hamil dengan riwayat preeklampsia, dan (3) peran Renin Angiostensin Aldosteron System (Hormon yang mengatur keseimbangan tekanan darah dan cairan).

\section{g. Pemeriksaan Antenatal Dengan} Kejadian Preeklampsia.

Hasil uji Chi-Square menunjukkan nilai p 0,085 artinya pemeriksaan antenatal dengan kejadian preeklampsia tidak mempunyai hubungan bermakna. Hasil ini dapat disebabkan karena ibu hamil lebih banyak telah melakukan pemeriksaan $>4$ kali sehingga terjadinya kasus preeklampsia sangat rendah juga. Hasil penelitian ini berbeda dengan beberapa hasil penelitian yang sama dengan metode case control study sebagai berikut: penelitian yang melaporkan bahwa adanya hubungan yang bermakna antara pemeriksaan antanatal dengan kejadian preeklampsi dengan nilai $\mathrm{p}$ sebesar 0,03 dan nilai OR 2,72, (22) sama halnya dengan hasil penelitian sebelumnya yang menyebutkan bahwa seorang ibu hamil preeklampsia dengan frekuensi ANC kurang atau sama dengan 4 kali mempunyai kecendrungan untuk mengalami preeklampsi, dimana ibu hamil yang frekuensi ANC kurang atau sama dengan 4 kali dalam kehamilannya mempunyai risiko 1,50 kali untuk terjadi terjadi preeklampsi dibandingkan dengan seorang ibu hamil preeklampsia yang frekwensi ANC lebih dari 4 kali. (6)

Berdasarkan analisis multivariat dengan malakukan uji secara bersama-sama pada semua variabel maka diperoleh dua variabel yang dominan atau mempunyai hubungan erat terhadap terjadinya preeklampsia yaitu faktor riwayat hipertensi dan faktor paritas, hasil ini menunjukkan bahwa faktor riwayat hipertensi dan faktor paritas sangat berpengaruh terjadinya kejadian preeklampsia.

Faktor riwayat hipertensi menjadi salah satu variabel yang dominan berpengaruh pada kejadian preeklampsia. Hasil analisis multivariat didapatkan nilai $\mathrm{p}$ 
0,001 dan OR 5,3 dengan tingkat kepercayaan (CI) $95 \%$ maka secara statistik menunjukkan bahwa riwayat hipertensi sangat berisiko pada kejadian preeklampsia. Hasil ini menunjukkan ibu dengan riwayat hipertensi cenderung terjadi preeklampsia. Faktor riwayat hipertensi dapat disebabkan oleh tingginya prevalesi hipertensi di provinsi Sulawesi Utara yaitu sebesar $27,1 \%$ dan sebagai provinsi tertinggi yang cenderung meningkat prevalensi hipertensi sekitar 16\% dibandingkan dengan provinsi lain yang rata-rata cenderung meningkat berkisar 9,5\% (23). Data ini dapat menggambarkan bahwa banyak ibu hamil yang telah memiliki riwayat hipertensi sehingga mempunyai kecenderungan untuk terjadi preeklampsia. Angka kejadian preeklampsia akan meningkat pada hipertensi kronis, karena pembuluh darah plasenta sudah mengalami gangguan. Faktor predisposisi terjadinya preeklampsia adalah hipertensi kronik dan riwayat keluarga dengan preeklampsia. Bila ibu sebelumnya sudah menderita hipertensi maka keadaan ini akan memperberat keadaan ibu.

Faktor paritas juga menjadi salah satu variabel yang dominan berpengaruh pada kejadian preeklampsia. Hasil analisis multivariat didapatkan nilai $\mathrm{p}$ 0,01 dan OR 3,8 dengan tingkat kepercayaan (CI) $95 \%$ maka secara statistik menunjukkan bahwa paritas sangat berisiko pada kejadian preeklampsia. Hasil ini menunjukkan ibu dengan paritas primi atau grandemulti cenderung terjadi preeklampsia. Hasil penelitian ini sesuai dengan penelitian yang menunjukkan bahwa paritas merupakan faktor risiko terhadap kejadian preeklampsia dengan nilai OR 2.67.
Persalinan yang berulang-ulang seperti grandemultigravida akan mempunyai banyak risiko terhadap kehamilan, telah terbukti bahwa persalinan kedua dan ketiga adalah persalinan yang paling aman.

Preeklampsia merupakan penyakit yang langsung disebabkan oleh kehamilan, walaupun belum jelas bagaimana hal ini terjadi. Teori lain menjelaskan bahwa ciri tipikal pasien diantaranya nulipara, preeklampsia merupakan penyakit primer bagi kehamilan pertama (primigravida). Demikian juga dengan kehamilan yang berulang-ulang yang terjadi pada ibu yang memiliki jumlah anak yang banyak disebabkan oleh faktor kehamilan yang tidak diinginkan dikarenakan ketidakpatuhan terhadap program KB misalnya lupa meminum pil $\mathrm{KB}$, lupa melakukan suntik. Pengetahuan yang kurang akan jumlah anak membuat para ibu tidak menyadari akan bahaya bagi kehamilan dan janinnya. Faktor yang mempengaruhi paritas antara lain latar belakang budaya yaitu adanya anggapan bahwa semakin banyak jumlah anak, maka semakin banyak rejeki.

\section{KESIMPULAN}

Sesuai hasil analisis hubungan masing-masing variabel penelitian dengan kejadian preeklampsia maka: umur, paritas, riwayat hipertensi, riwayat keluarga, dan riwayat preeklampsia memiliki hubungan yang signifikan dengan kejadian preeklampsia. Sedangkan obesitas dan pemeriksaan antenatal tidak mempunyai hubungan yang signifikan dengan kejadian preeklampsia. Variabel penelitian yang sangat dominan berpengaruh terhadap kejadian preeklampsia yaitu riwayat hipertensi berpengaruh terhadap kejadian 
preeklampsia. Responden dengan riwayat hipertensi mempunyai peluang untuk terjadi preekalampsi (berulang) sebesar 5,3 kali dibandingkan ibu yang tidak ada riwayat hipertensi. Demikian juga dengan paritas sangat dominan berpengaruh terhadap kejadian preeklampsi, responden dengan paritas primigravida dan multigravida mempunyai peluang untuk terjadi preekalmpsi sebesar 3,8 kali dibandingkan paritas multigravida.

\section{SARAN}

1. Ibu hamil yang mempunyai riwayat hipertensi untuk diit makanan yaitu makanan tinggi protein, tinggi karbohidrat, cukup vitamin, dan rendah lemak. Kurangi garam apabila berat badan bertambah atau edema, istirahat yang cukup dan pengawasan antenatal selama kehamilan dengan meningkatkan kunjungan pemeriksaan agar dapat dideteksi secara dini.
2. Instansi unit pelayanan kesehatan dalam pengelolaan Pelayanan Kegawatdaruratan Obstetri dan Neonatal Emergensi Komprehensif (PONEK) agar dapat dilakukan dengan cepat sehingga kasus preeklampsia pada ibu hamil dapat terdeteksi sedini mungkin dan dapat tertangani oleh tenaga kesehatan dengan tepat.

3. Dinas Kesehatan Provinsi Sulawesi Utara agar dapat menyediakan akses pelayanan Pelayanan Kegawatdaruratan Obstetri dan Neonatal Dasar (PONED) di tingkat Puskesmas dan meningkatkan promosi atau penyuluhan tentang tandatanda bahaya pada kehamilan di tingkat Puskesmas.

4. Bekerja sama dengan lintas sektoral seperti BKKBN untuk menekan jumlah paritas karena kehamilan yang berulangulang sangat berisiko terjadinya penyulit atau komplikasi.

\section{DAFTAR PUSTAKA}

1. Prawirohardjo S. Ilmu Kebidanan. Jakarta: Yayasan Bina Pustaka-Sarwono Prawirohardjo; 2009.

2. Kemenkes. Profil Kesehatan Kementerian Kesehatan Republik Indonesia. 2013.

3. Abdul. Penanganan Preeklampsia. ARCAN; 2006.

4. Asrianti T. Faktor Resiko Kejadian Pre-eklampsia pada Ibu Melahirkan di RSIA Siti Fatimah Makasar. Univ Hasanudin. 2009;

5. Rivers, L.A.N, Chantry, C.J., Peerson, J.M., Cohen, R.J., Dewey, K.G. Delayed Onset Of Lactogenesis Among Firsttime Mothers Is Related To Maternal Obesity And Factors Associated With Ineffective Breastfeeding. Am J Clin Nutr [Internet]. 2010;92(3):574-84. Available from: https://academic.oup.com/ajcn/article/92/3/574/4597439

6. Rozikhan. Faktor-Faktor Risiko Terjadinya Preeklampsia Berat Di Rumah Sakit Dr. H. Soewondo Kendal. Universitas Diponegoro Semarang; 2007.

7. Ekowati S. Prevalensi Hipertensi dan Determinannya di Indonesia. Pus Penelit Biomedis dan Farm Badan Penelit Kesehat Depkes RI. 2009;

8. Chairiah. Pengaruh Pola Makan dan Status Gizi Terhadap Kejadian Hipertensi Pada Ibu Hamil Di RSU Tanjung Pura Kabupaten Langkat. Univ Sumatera Utara. 2012;

9. Saifudin. Pelayanan Kesehatan Maternal Dan Neonatal. Yayasan Bina Pustaka Sarwono Prawirohardjo; 2006.

10. Prawirohardjo Sarwono. Buku Acuan Nasional Pelayanan Kesehatan Maternal dan Neonatal. Jakarta: PT Bina Pustaka Sarwono Prawirohardjo; 2010.

11. Li, Y., Townend, J., Rowe R., Knight M., Brocklehurst P. HJ. The Effect Of Maternal Age And 
Planned Place Of Birth On Intrapartum Outcomes In Healthy Women With Straightforward Pregnancies: Secondary Analysis Of The Birthplace National Prospective Cohort Study. Bio Med J Open. 2014;

12. Wahyuny. Faktor Risiko Kejadian Preeklampsia di RSKD Ibu dan Anak Siti Fatimah Makasar Tahun 2011-2012. 2012;

13. Utama SY. Faktor Risiko yang Berhubungan dengan Kejadian Preeklampsia Berat pada Ibu Hamil di RSD Raden Mattaher Jambi Tahun 2007. J Ilm Univ Batanghari Jambi. 2008;8(PREEKLAMSIA):52-8.

14. Derek L. Dasar-Dasar Obstetric Dan Ginekologi. Hadyanto, editor. 2001.

15. Mc.Call P. Sellers; Midwifery, A Tekbook And Reference Book For Midwifery In Southern Africa. Complication in Childbirth; 2003.

16. GM, Duffus, I, MacGillivray. The incidence of pre-eclamptic toxaemia in smokers and nonsmokers. Lancet [Internet]. 1968;1(7550):994-5. Available from: https://www.ncbi.nlm.nih.gov/pubmed/4171836

17. Rozikhan R. FAKTOR-FAKTOR RISIKO TERJADINYA PREEKLAMPSIA BERAT DI RUMAH SAKIT Dr. H. SOEWONDO KENDAL (Doctoral dissertation, Program Pasca Sarjana Universitas Diponegoro). 2007;

18. Lalita E. Asuhan Kebidanan Kehamilan. In Media; 2013.

19. Cunningham. Obstetri William. Hartono JS dan A, editor. New York:Mc Graw Hill; 2001.

20. Cunningham FG. Obstetri William. 1st ed. Andry Hartono, editor. Jakarta: EGC; 2005.

21. Zakiah. Faktor-Faktor Yang Mempengaruhi Terjadinya Hipertensi Pada Ibu hamil Di Rumah Sakit Khusus Daerah Ibu dan Anak Siti Fatimah Makassar. 2012;

22. Langelo W, A.Arsin A, Russeng S. Faktor Risiko Kejadian Preeklampsia di RSKD Ibu dan Anak Siti Fatimah Makasar Tahun 2011-2012. Universitas Hassanudin Makasar; 2012.

23. Kemenkes. Riset Kesehatan Dasar. Jakarta; 2013.

24. Fang, R., Dawson, A., Lohsoonthorn, V. and Williams MA. Risk factors of early and late onset preeclampsia among Thai women. Asian Biomed Res Rev news. 2009;3(5), 477.

25. Fang R, Dawson A, Lohsoonthorn V, Williams MA. Risk Factors of Early and Late Onset Preeclampsia among Thai Women. Asian Biomed (Res Rev news). 2009;3(5):477-86. 